\title{
War is hazardous for your health: photographs and testimonies about death, wounds, disease and medical care during the Mexican Revolution
}

\author{
Guerra é prejudicial à sua saúde: fotografias e testemunhos \\ sobre morte, ferimentos, doenças e cuidados médicos \\ durante a Revolução Mexicana
}

John Mraz

Pesquisador do Instituto de Ciencias Sociales y Humanidades Alfonso Vélez Pliego/Benemérita Universidad Autónoma de Puebla. Madroño 23

04610 - Coyoacán - México DF México

mraz.john@gmail.com
MRAZ, John. War is hazardous for your health: photographs and testimonies about death, wounds, disease and medical care during the Mexican Revolution. História, Ciências, Saúde - Manguinhos, Rio de Janeiro, v.18, n.3, jul.-set. 2011, p.893-905.

\section{Abstract}

Revolutionary wars have devastating and far-reaching effects on the health of the populations caught up in them. However, the deaths and injuries produced by weaponry are only part of the story, because diseases resulting from malnutrition and contaminated drinking water account for the majority of medical problems. This essay uses photographs and testimonies of participants to explore health issues during the Mexican Revolution (1910-1920), as well as incorporating secondary literature on this question. Furthermore, photographic images are not presented as simple (indexical) windows onto the world. Rather, the author attempts to identify the imagemakers and provide explanations that help in imagining the reasons behind the making of the photographs

Keywords: Mexican Revolution (1910-1920); historical photographs; health in wars; demography; oral history.

\section{Resumo}

Revoluções armadas têm efeitos devastadores e de longo alcance sobre a saúde das populações envolvidas. No entanto, mortes e ferimentos produzidos por armas são apenas parte da história, pois doenças resultantes de má nutrição e contaminação da água potável são responsáveis pela maior parte dos problemas médicos. O artigo utiliza fotografias e testemunhos de participantes para investigar questões de saúde durante a Revolução Mexicana (1910-1920), incorporando também literatura secundária sobre a questão. As imagens fotográficas não são apresentadas simplesmente como janelas (indexadores) para o mundo. Tenta-se identificar os autores das imagens e construir explanações que ajudem a imaginar as razões por que cada fotografia foi tirada.

Palavras-chave: Revolução Mexicana (1910-1920); fotografias históricas; saúde nas guerras; demografia; história oral. 
$\mathrm{T}$ he Mexican Revolution (1910-1920) was one of the world's great conflagrations. Demographer Robert McCaa (2001, p.16) has estimated that this cataclysm would rank ninth in terms of loss of human life, surpassed only by the two World Wars, the Soviet Revolution, the Korean and Vietnam conflicts, the Napoleonic wars (1803-1815), the Sino-Japanese War (1937-1914), and the Soviet-Afghanistan conflict; it appears to be on a par with the Spanish Civil War (1936-1939). ${ }^{1}$ Although scholars tend to differ with regard to the demographic impact of the Mexican Revolution, total losses are considered to have been somewhere between two and 3.5 million, in a population estimated to have been 15 million at its onset (p.1). However, the deaths and injuries produced by weaponry are only part of the story, because diseases such as typhus, smallpox, malaria, yellow fever, and the "Spanish influenza" were "the single biggest killer", according to historian Alan Knight (1990, p.420). These diseases flourished because public hygiene and sanitation were neglected and the population suffered from prolonged malnutrition and contaminated drinking water.

Death became part of daily life. Among the more famous of the revolutionary corridos was "La Valentina"; its best-known chorus encapsulates the climate of the times: "Se me han de matar mañana que me maten de una vez" (If they are going to kill me tomorrow, let them do it now). One of the participants in that war commented, "Life was worth little at that time. So many people died in battle, so many were executed, that living another day wasn't very important" (Vallejo, 1966-1967, p.13). ${ }^{2}$ The Cachú brothers (Juan and Antonio) from Michoacán made their living during the Revolution by photographing its horrors, something for which their medical training may have prepared them. One task was that of picturing hanged followers of Francisco I. Madero, who had begun the struggle in 1910 and deposed the long-time dictator, Porfirio Díaz, only to be overthrown by Victoriano Huerta in February of 1913. The huertistas had forbidden the families to take the corpses down, so they asked the Cachús to make portraits of their loved ones for posterity. Their reason for capturing the image of the executed General José Pérez Castro (Figure 1) was of a different sort. ${ }^{3}$ The Cachús had evidently left Michoacán in 1914 to join the anti-Huerta forces. Pérez Castro was a reactionary guerrilla, who may have been simply one of the many bandits who took advantage of the chaotic situation to loot, rape and kill. Allied with Huerta and Pascual Orozco, he joined the latter to sack the city of León, Guanajuato, on 1 August 1914. When the city was retaken by General Alberto Carrera Torres, a revolutionary who was the first to proclaim land reform, Pérez Castro was captured and executed. Photographs of the dead commander were probably taken to celebrate the victory over the reactionary forces, and demonstrate the revolutionaries' control of outlaws.

Madero's rebellion had brought democracy to Mexico. However, to be destroyed by Huerta's coup d'etat, achieved (with the connivance of the United States) by La Decena Trágica (The Tragic Ten Days), a reactionary uprising during February 1913 in which the residents of Mexico City underwent merciless bombardment by Huerta's forces to ensure their eventual acceptance of Madero's removal. Many combatants and civilians were wounded or killed. Eduardo Vargas Sánchez was a young student during those ten long days and described how difficult it was to care for the wounded, and the role played by people who worked for aid agencies or simply tried to help, such as the woman in Figure 2 
(a picture that may have been taken by the postcard maker and erstwhile photojournalist, Félix Miret).

\begin{abstract}
The ambulances of the Neutral White Cross (a name adopted to protect them from the combatants' firing) and the blessed Red Cross could not cope with the vast numbers of injured, and some were left to bleed to death in the streets. But some people were so caring that they risked their own lives; they carried the wounded they found and did their best to cure them (Vargas Sánchez, 1985, p.155).
\end{abstract}

The many dead that lay in the Mexico City streets posed a serious health problem for the living. In order to avoid an epidemic, they were sometimes cremated where they had been found during those brief moments when residents were allowed to leave their houses to search for food and water. Young boys who had been pent up in their homes would run into the streets to see what new horror awaited them: "We were students of thirteen years or younger. During the truces we would sneak out and watch how the scores of corpses in the streets moved slowly when burned with gasoline. Their eyes would open and their arms, legs and fingers move with the fire's effect on their muscles and joints" (Vargas Sánchez, 1985, p.153). When those ten long days came to an end, photojournalist Samuel Tinoco took pictures of the corpses that had been carried outside the city to be piled up and burned (Figure 3).

The United States invaded Veracruz in April 1914 to oust Huerta in order to ensure that the revolution did not radicalize further, and thereby retain Mexico within the imperial sphere. The naval bombardment against the city resulted in numerous casualties. In Figure 4, a photo probably taken for publicity purposes (perhaps by port resident Ponciano Flores Pérez), numerous health workers attend a man evidently wounded by an incendiary bomb. The official history of Revolutionary medicine recounts: "Right from the start, our doctors, first and foremost professional, occupied their posts of honor in the military units or the rearguard to generously provide for better medical care" (Álvarez Amezquita et al., 1960, p.547). However, one of the doctors who participated in the armed struggle tells a different story: "The majority of the forces didn't have licensed doctors; those that attended were nurses or students. There were very few licensed doctors. Some had fled, others had died, and the majority didn't want to have anything to do with what was going on" (Guillén Zamora, 1966-1967, p.34).

Photographs provide testimony to the hardships endured by the population of Mexico, particularly those of Mexico City, since the photojournalists who would have recorded such scenes were overwhelmingly based in the metropolis. Hunger spread as the revolution prolonged, and the years 1915-1918 were especially difficult. "Fruit, vegetables, and cereals didn't reach the city; even if there were any in the nearby states, they couldn't be transported because the railroads were allocated solely for military purposes" (Ulloa, 1982, p.79). Political decisions also played their part: according to Knight (1990, p.418), "As the new Constitutionalist elite consolidated itself in power, matters grew worse rather than better". The authorities used the shortages to traffic foodstuffs for personal profit; at the same time, food was often exported to secure arms and foreign exchange. Consequently, city residents spent long hours waiting in line (Figure 5). One survivor recalled: "Families 
John Mraz

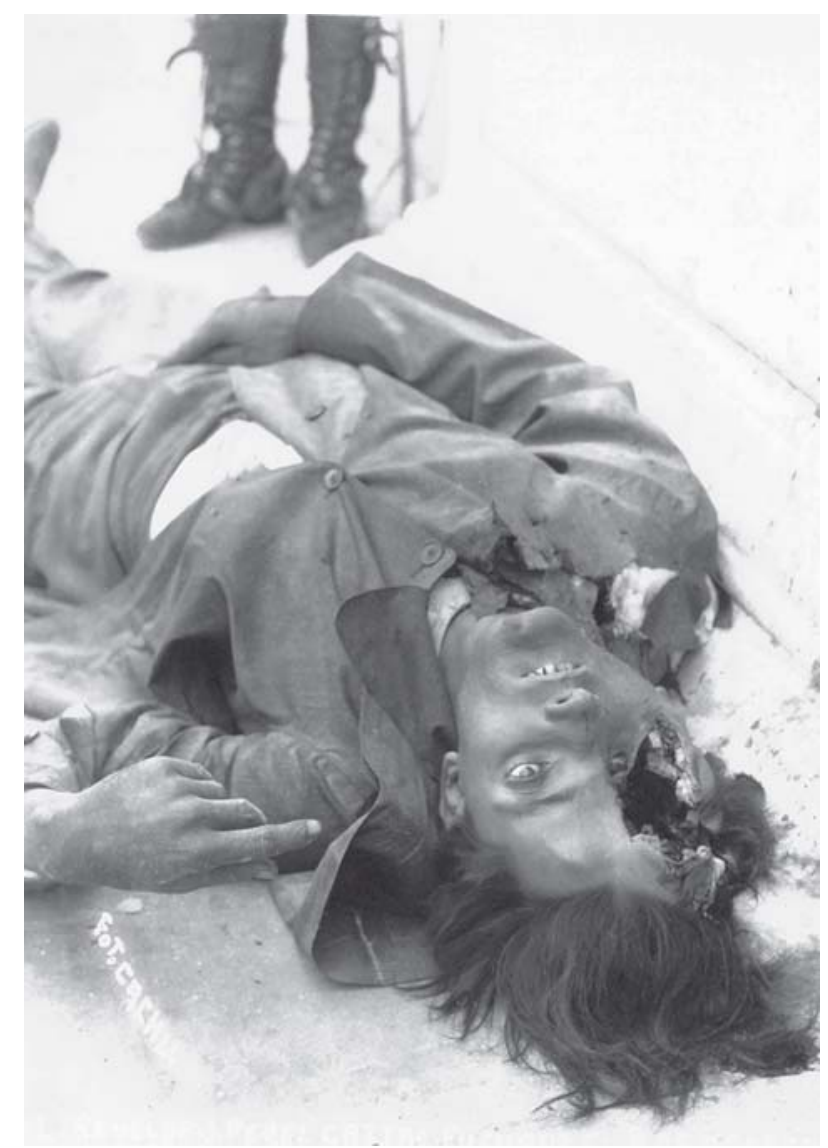

Figure 1: General José Pérez Castro, executed in León, Guanajuato, 3 August 1914 by General Alberto Carrera Torres; Cachú brothers (Fondo Cachú-Ramírez, Juan; Departamento de Información y Documentación de la Cultura Audiovisual/ Benemérita Universidad Autónoma de Puebla)

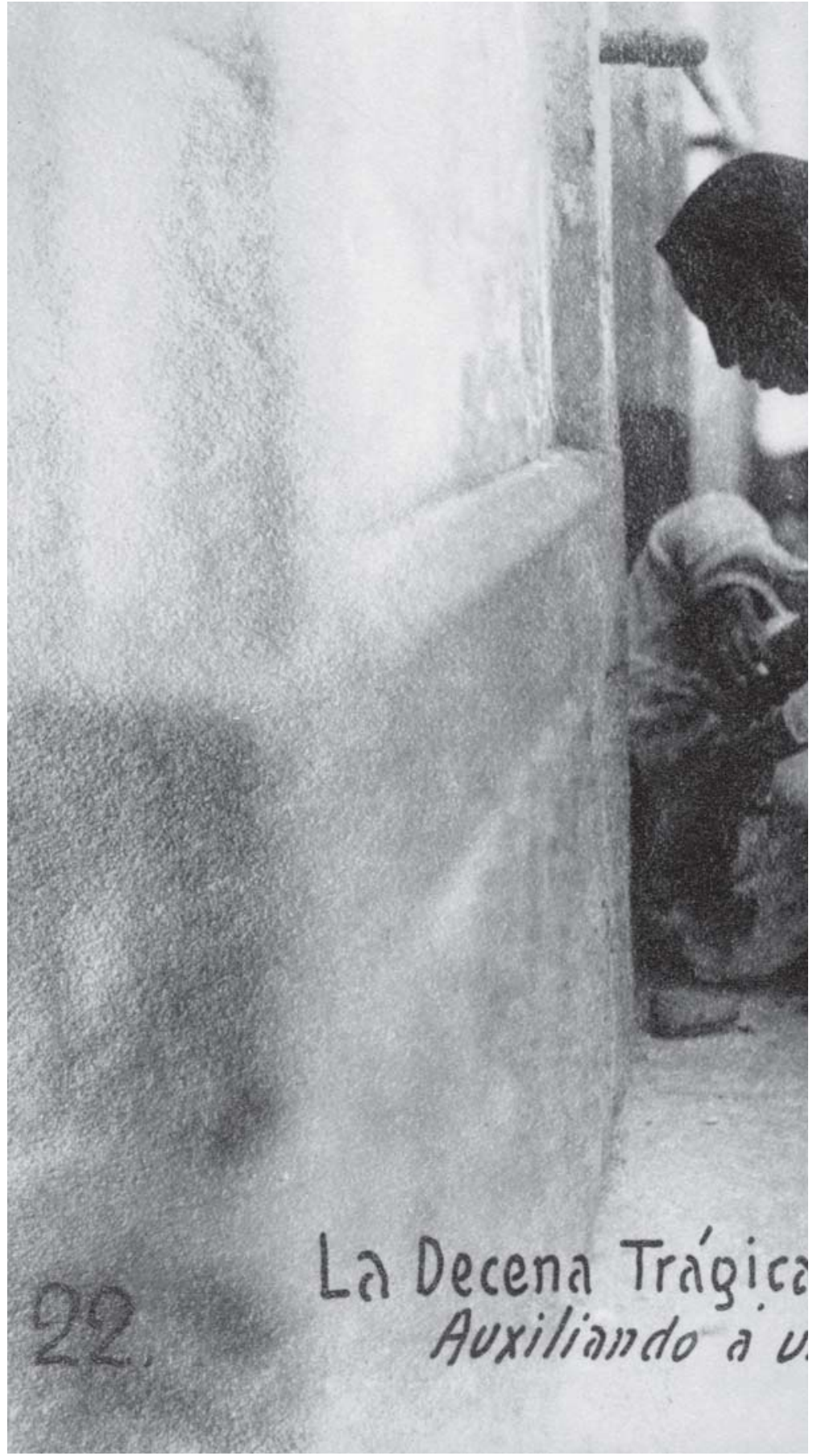

Figure 2: Woman helps a wounded person; Mexico City,

February of 1913; Félix Miret (Inv.\#451501, Fondo Casasola, Sinafo-Fototeca Nacional del Inah) 


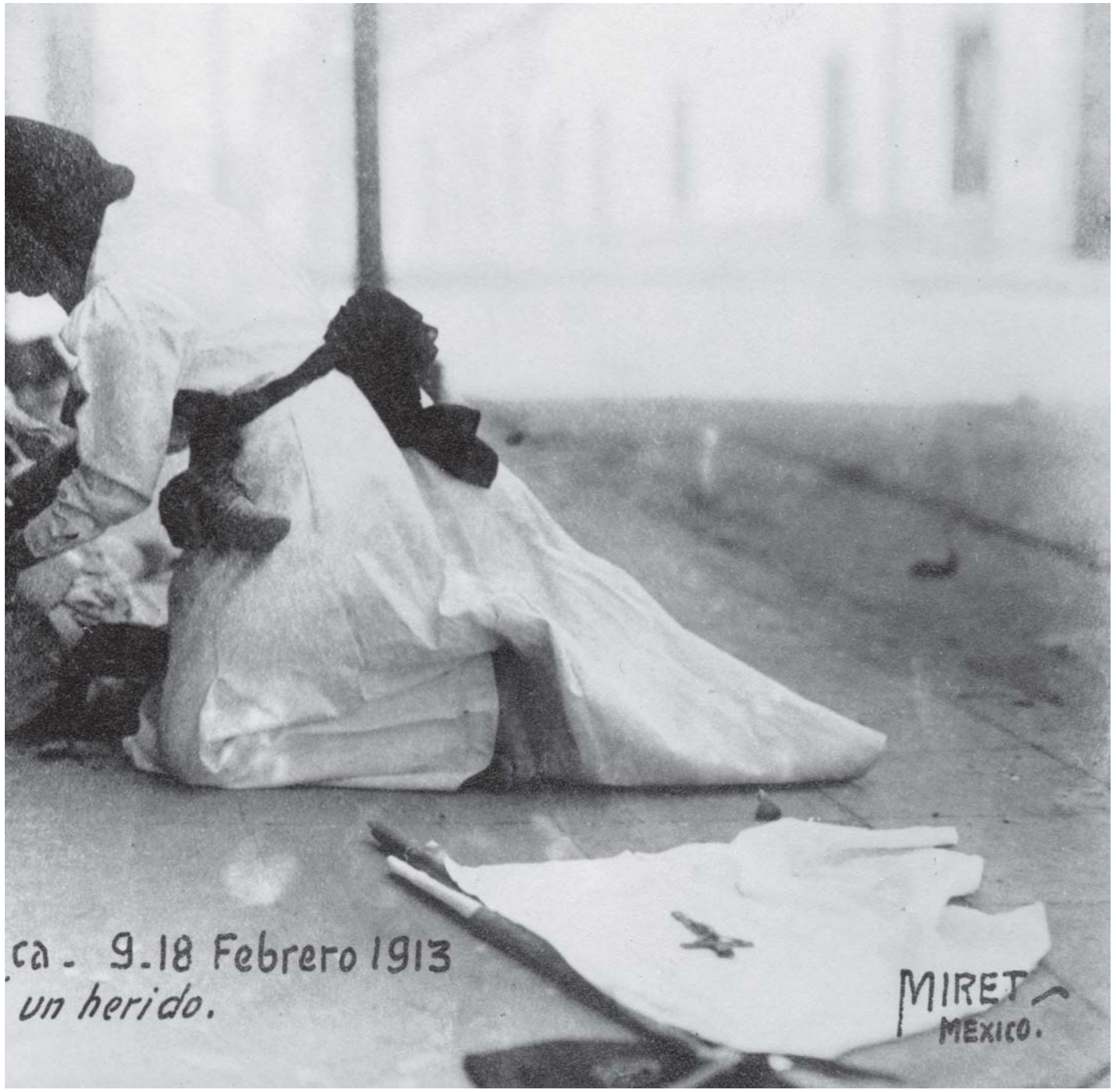




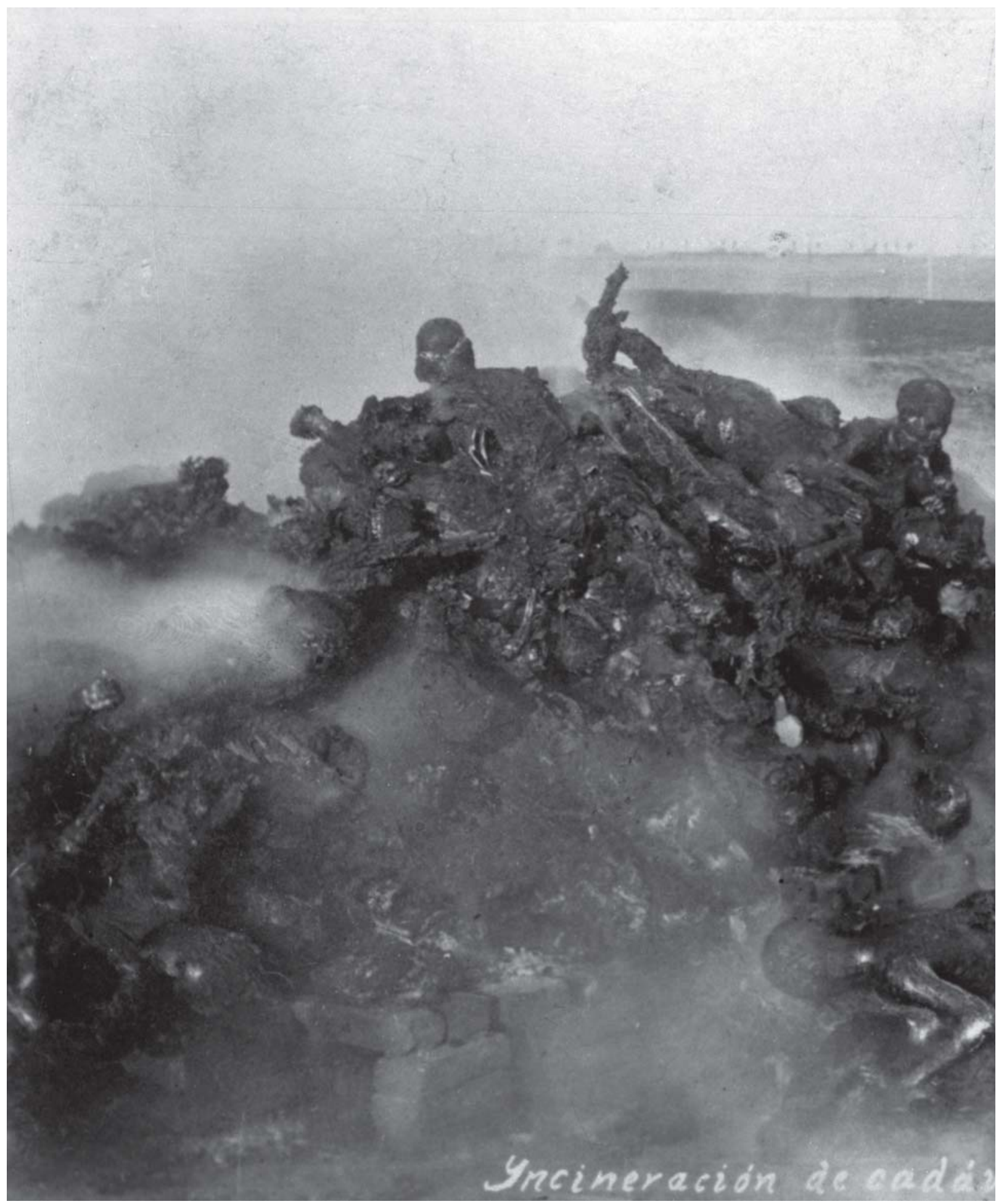

Figure 3: Burning corpses in Balbuena; Mexico City, February 1913; Samuel Tinoco (Inv.\#37306, Fondo Casasola, Sinafo-Fototeca Nacional del Inah) 


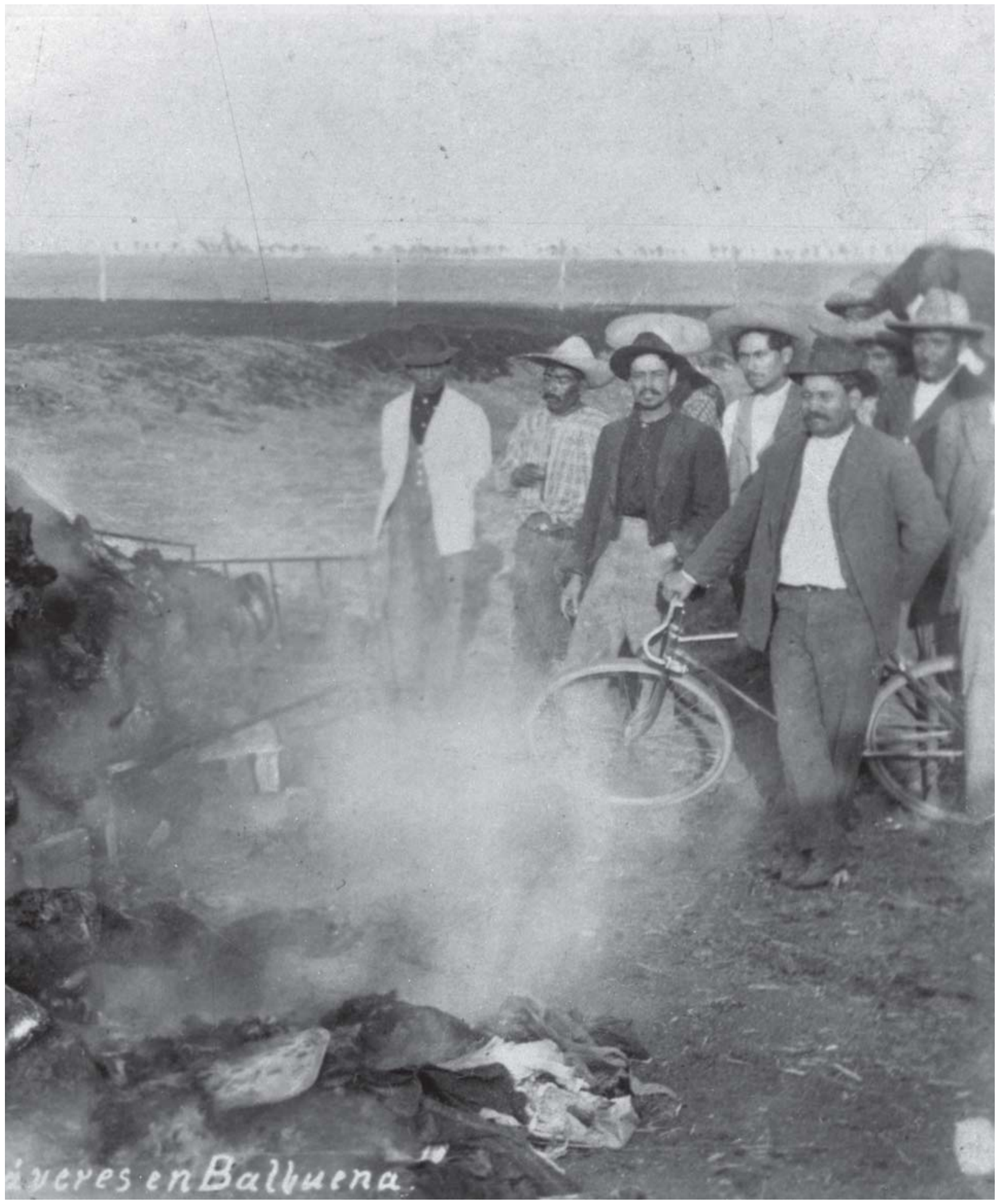




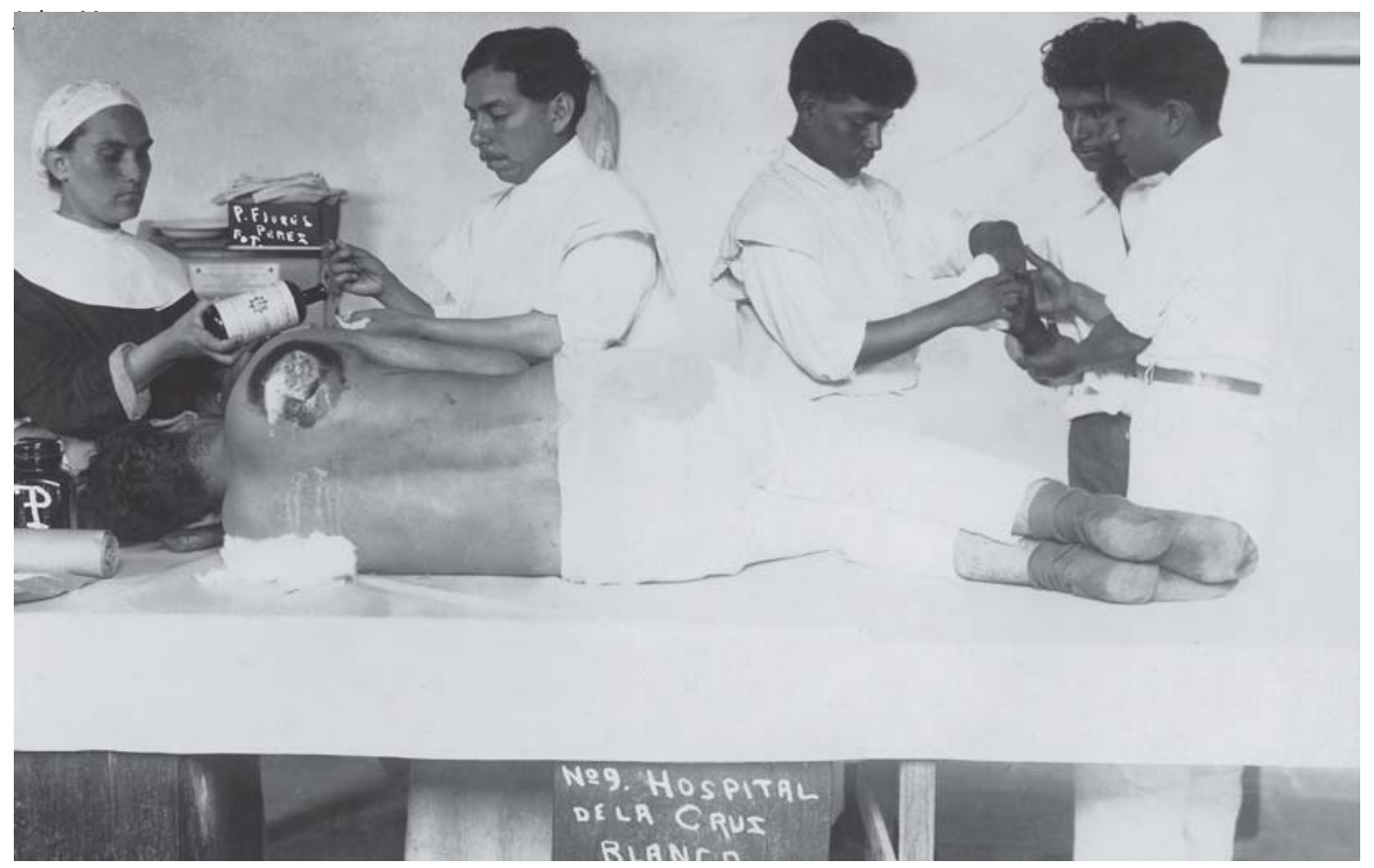

Figure 4: Medical personnel with wounded; port of Veracruz, April of 1914 (Inv.\#373917, Fondo Casasola, Sinafo-Fototeca Nacional del Inah)

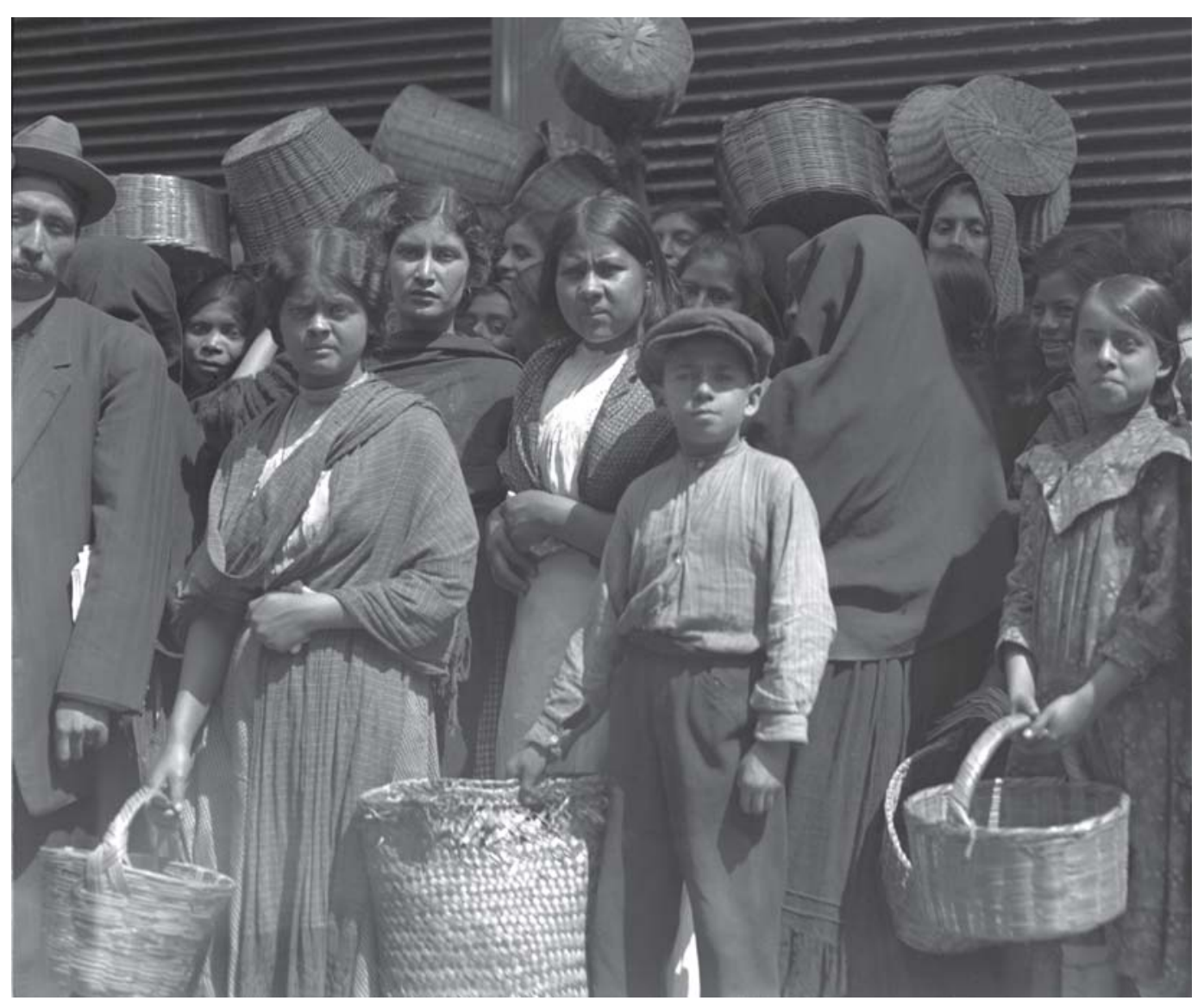

Figure 5: People waiting for food; Mexico City, ca. 1915 (Inv.\#5999, Fondo Casasola, Sinafo-Fototeca Nacional del Inah) 
had to stand in line entire days and nights for food; the women would take small stools as they waited in line and sit down for a few minutes. Some had to wait in line for two or three days and nights because when they arrived at the store everything was gone and they had to wait until more bread and milk were brought" (Vargas Sánchez, 1985, p.180).

Malnutrition contributed to the rising death rate and diseases, such as gastric fevers resulting from food retrieved from garbage dumps. Francisco Ramírez Plancarte (1941, p.348) described the extreme situation in which he had lived:

People's hunger was so great that many fainted. Crowds of indigents picked up fruit peels from the ground, and would gobble them down even though they were filthy. Others used poles to poke among the great mountains of garbage around the markets in the hope of finding some leftover poultry, fruit, vegetables, or entrails, even if they were rotten; their sole desire was to somehow placate the hunger that devoured them.

Other problems just as serious as hunger were documented in what were invariably photojournalistic images. The shortage of water was constant, both because of the demands by the occupying armies and the lack of maintenance to the system. Figure 6 shows families in Mexico City waiting to fill their buckets with the precious liquid. Eduardo Vargas Sánchez (1985, p.170) again offered a nightmarish testimony:

Men were killed on both sides during the shootouts and their bodies fell into the water, where they rotted. It occurred to me to send for some long ropes and poles that were used in the poorer neighborhoods as clothes lines, and we employed them and a sort of apron to pull out some of the lighter corpses. However, when the giant Yaqui Indian soldiers fell to the bottom of the springs it was impossible to retrieve them. They were especially heavy because they usually wore cartridge belts crossed from their left shoulder to their right hip and from their right shoulder to their left hip, as well as two more around their waists. That was the water that was drunk in the city and the source of all kinds of disease.

Constitutionalism was the most photographed revolutionary movement (as well as being that of which the most images survive). There were more Constitutionalist photographers and they took more pictures for the same reason that army won the war: they had more money. The number of photographs and photographers is testimony to their predominance in matters of representation, and their propaganda machine included the founding of a bilingual magazine, with photographs, to promote their interests in the U.S., The Mexican Review/Revista Mexicana. The extensive documentation of the Constitutionalist movement opens windows onto various facets of the advantages enjoyed by those forces. One example is the image of an orderly hospital, the soldiers in their beds and attended by doctors; of course, the very pulchritude of the scene may have been the reason behind making the photograph (Figure 7). However, participant and writer Martín Luis Guzmán (1978, p.143-145) reminds us that war is hell, even for those with the upper hand:

I looked at the double row of beds, the cots spread around in rooms full of the wounded, and it was strange to discover in every bed (or every pallet or every chair) the master work of a diabolic entertainment. Separately, each wound revealed the existence of a particular category of bullet, of the personality behind each projectile at the moment to deliver its blow. There were bullets that de-nosed and de-chinned; those that multiplied idly the purifying escapes of the organism; those that perforated the abdomen to cause peritonitis; 

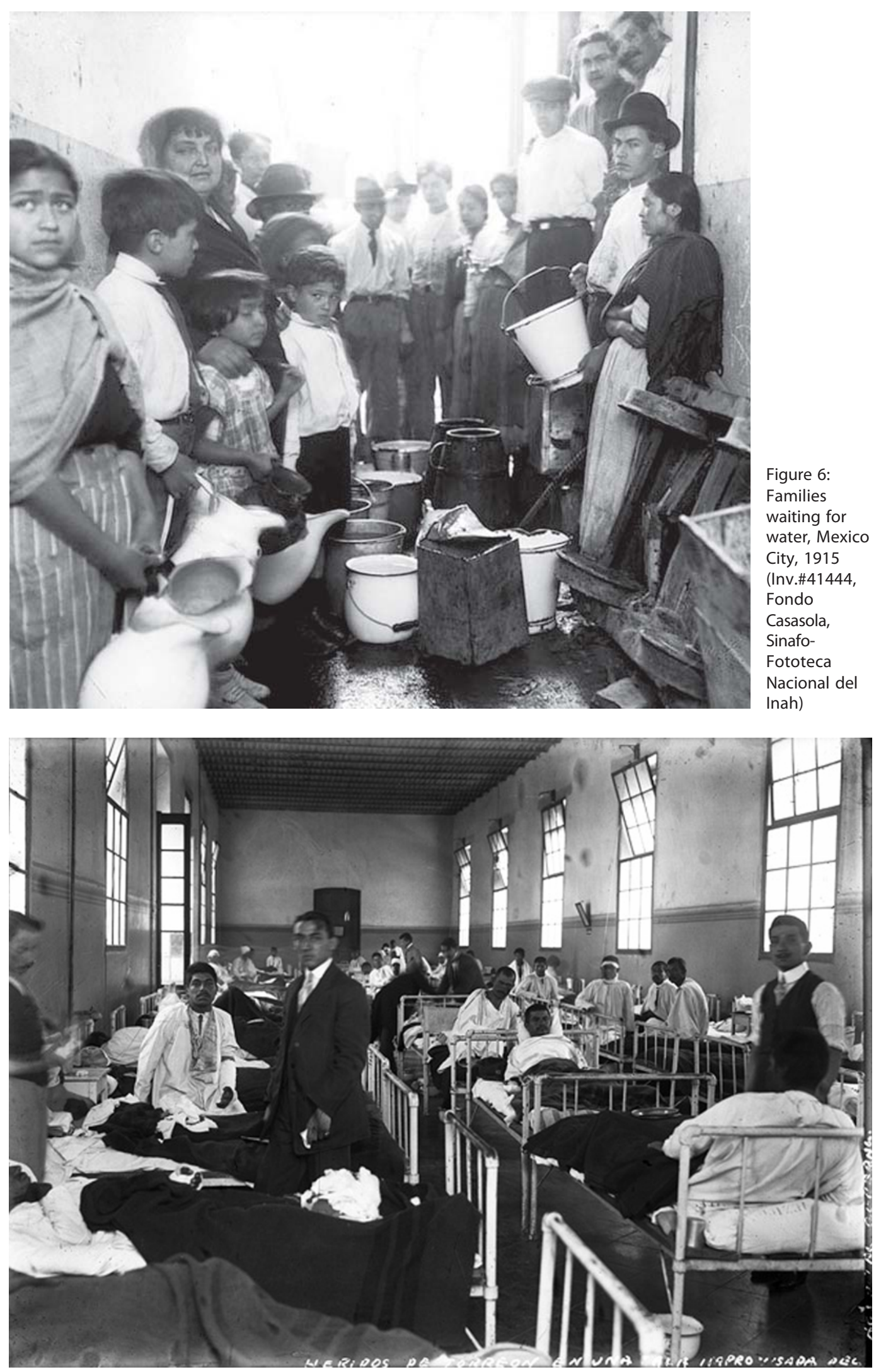

Figure 7: Military hospital, Torreón, Coahuila, ca. 1915 (Inv.\#64597, Fondo Casasola, Sinafo-Fototeca Nacional del Inah) 
those that left in the brain an everlasting din of cataracts or an irresistible shining, more intense than if the sun were in the eyes; those that created for the rest of one's life, outbreaks of shivering, breakdown, pain, of embarrassing inertias in the organs of the most necessary and constant functions. That soldier who can never sit down! That other who has to complete his mouth with the palm of his hand in order to eat! That one who cannot bend his left knee or straighten his right! That one, within whom the slightest variations of temperature accumulate, with the sensation of hot coals or of ice flowing along his spine!

The Spanish Flu of 1918-1919 was a respiratory pandemic that swept the world, killing somewhere between 20 and 50 million people (Cuenya Mateos, 2010, p.151). Compared to other epidemics in Mexico, such as typhus, it was short-lived and the worst stage lasted about three months: September, October and November 1918. Venustiano Carranza had been installed as president of Mexico, and the revolution had essentially been decided in favor of the Constitutionalist forces. Although the nation enjoyed some measure of peace, the widespread destruction and lack of maintenance of sanitary facilities, the malnutrition of a disease-weakened population and the insufficient number of physicians, medication and hospital beds all contributed to ranking the Mexican mortality rate from the flu the third highest in the world; the total of around 300,000 deaths measures 20 per 1,000 (Knight, 1990, p.421-422) (Figure 8). The government's sanitary policies took several forms: transportation between infected communities was interrupted; gathering places such as theaters, clubs, schools and bars were closed; people were warned to keep away from reunions, to cover their mouths and noses when coughing and sneezing, to avoid kissing or shaking hands when greeting, and to breathe through their nose rather than their mouth (Márquez Morfín, Molinar del Villar, 2010, p.138). The ailing were requirred to report to hospitals, which became quickly saturated.

The Constitutionalists were masters of public relations and tended to adopt symbolic acts rather than focus on solving the problems; hence, Figure 8 may have been a set-up designed to convince Mexico City's inhabitants of an active anti-flu campaign. Although historians have yet to substantiate the allegation, one survivor's recollection suggests that the government may have resorted to extreme measures to control the disease's spread. Arcadio Rico de la Cruz remembered the following episode:

One day, around three in the afternoon, word spread around the house: "Here comes the nurse brigade". I had my head wrapped up and I was under a blanket, but I very quickly took off the wrap and threw the blanket aside, rolled up my sleeves and stood up; I had to lean against the wall the whole time but I wanted to try to whistle. I did all that so that I wouldn't be given the death pills (the pills the nurses handed out so that people would die). Fortunately, they didn't come into the house and I recovered from my scare (Ramírez Racaño, 2009, p.69).

Eight pictures and a few testimonies can only begin to describe the Mexican Revolution's devastating and far-reaching effects on the population's health. Of course, neither of these documents provides that open window onto the past that historians yearn for while knowing that it is unattainable. Although photographic transparency is an interesting notion to explore heuristically in relation to social history, we should always be aware that 
we are seeing through the agendas that the photographers (and their sponsors) brought to picturing the revolution, be that the pay or the forums offered by a group or a publication, or their own commitment to a particular cause or to ideas they wished to communicate.

We must bear in mind the fundamental difference between those who write and those who photograph: it costs money to portray in technical images, and those who work with them must incur expenses for film, chemicals, cameras, tripods, assistants and equipment. In this spirit, I have tried to briefly reflect upon the possible background of some pictures in order to allude to the complexity (and importance) of finding the reasons behind the making of a photograph, what we might call its 'authorship'. Who, finally, makes a photograph? Is it a product of the intellectual authors who provide the material and ideological contexts in which images are created? Or is it an expression of those who frame the scene, click the shutter, print their slivers of life and then hand them over to their new owners, who will use them in their own interests (as I have done in this essay)?

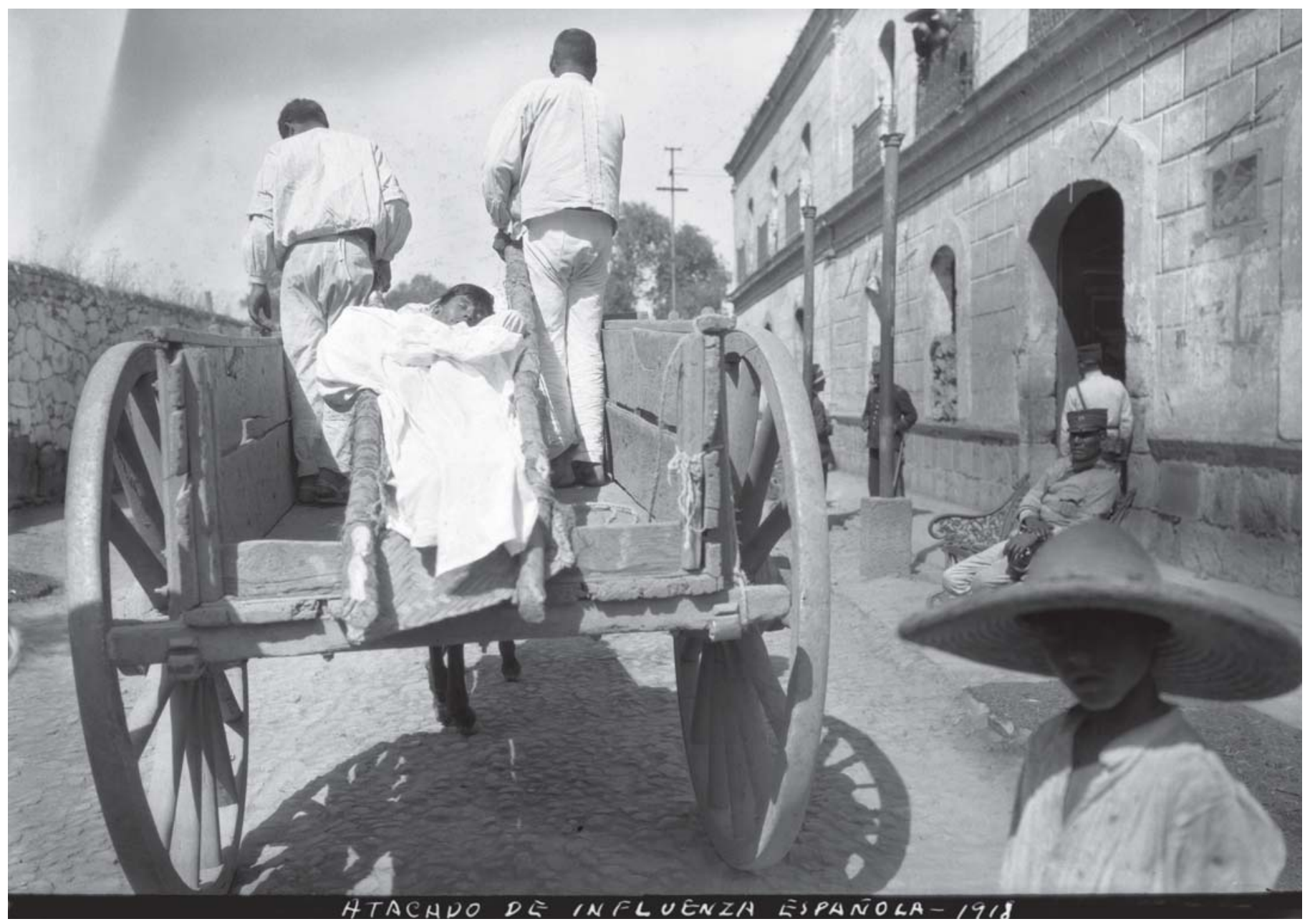

Figure 8: Soldier sick with Spanish flu, Mexico City, 1918 (Inv.\#75735, Fondo Casasola, Sinafo-Fototeca Nacional del Inah) 


\section{NOTES}

${ }^{1}$ McCaa's article was written before the Iraq War, whose casualties are estimated at one million. It is not clear why the Chinese Revolution has not been included in the list.

${ }^{2}$ In this and other citations of texts from non-English languages, a free translation has been provided.

${ }^{3}$ Readers may find it of interest that this photo was censured from the national exhibit of which I was curator for the Instituto Nacional de Antropología e Historia on the Centenary of the Mexican Revolution, "Testimonios de una Guerra. Imágenes de la Revolución Mexicana". However, it appears in the book I authored, Fotografiar la Revolución Mexicana: compromisos e íconos (Mraz, 2010), together with another 190 photos of that struggle. This book will appear in English, Photographing the Mexican Revolution: commitments, testimonies, icons, Austin: University of Texas Press, forthcoming.

\section{REFERENCES}

ÁLVAREZ AMEZQUITA, José et al.

Historia de la salubridad y de la asistencia en México. Mexico City: Secretaría de Salubridad y Asistencia. 1960.

CUENYA MATEOS, Miguel Ángel.

Reflexiones en torno a la pandemia de influenza de 1918: el caso de la ciudad de Puebla. Desacatos, Mexico City, n.32, p.145-158. 2010.

GUILLÉN ZAMORA, Fidel.

Somos estudiantes de medicina. Crónica Ilustrada Revolución Mexicana, Mexico City, n.56, p.34. 1966-1967.

GUZMÁN, Martín Luís.

El águila y la serpiente. Mexico City: Ediapsa. (Colección Málaga). 1.ed., 1928. 1978.

KNIGHT, Alan.

The Mexican Revolution: counter-revolution and reconstruction. Lincoln: University of Nebraska Press. v.2. 1990.

MÁRQUEZ MORFÍN, Lourdes; MOLINAR DEL VILLAR, América.

El otoño de 1918: las repercusiones de la pandemia de gripe en la Ciudad de México. Desacatos, Mexico City, n.32, p.121-144. 2010

MCCAA, Robert.

Missing millions: the human cost of the Mexican Revolution. Available at: http:// www.hist.umn.edu/ rmccaa/missmill/. Access on: Aug. 30, 2011. 2001.
MRAZ, John.

Fotografiar la Revolución Mexicana:

compromisos e íconos. Mexico City: Instituto

Nacional de Antropología e Historia, 2010.

RAMÍREZ PLANCARTE, Francisco.

La Ciudad de México durante la Revolución Constitucionalista. Mexico City: Edición Botas. 1941.

RAMÍREZ RACAÑO, Mario.

La epidemia de influenza española en México: 1918. 20/10: Memoria de las Revoluciones en México, Mexico City, n.4, p.68-93. 2009.

ULLOA, Berta.

La revolución escindida. Mexico City: El Colegio de México. (Historia de la Revolución Mexicana, vol. 4). 1982.

VALLEJO, Juan M.

Corresponsal de guerra. Crónica Ilustrada Revolución Mexicana, Mexico City, n.35, p.13. 1966-1967.

VARGAS SÁNCHEZ, Eduardo.

La Ciudad de México de 1900 a 1920. In: Bonfil, Guillermo (Ed.). Mi pueblo durante la revolución: un exercicio de memoria popular. Mexico City: Instituto Nacional de Antropología e Historia. p.151-190. 1985.

\section{$\rightarrow \rightarrow \rightarrow<<<$}

